\title{
The Totipotency and Relationship of Seta-Bearing Cells to Thallus Development in the Green Alga Coleochaete Scutata. A Laser' Microbeam Study
}

\author{
Gordon McBride, Jean LaBounty, Julian Adams, and Michael Berns \\ Department of Botany, University of Michigan, Ann Arbor, Micigan 48104 and Department of Development \\ and Cell Biology, University of California, Irvine, California 92664
}

Accepted October 10, 1973

\begin{abstract}
The relationship of seta-bearing cells of Coleochaete scutata (Chlorophyta Ulotrichales) to normal growth and development of the thallus was investigated using laser microbeam irradiation. When all of the seta-bearing cells of a thallus, except the small primary seta-bearing cell, were destroyed by laser microbeam irradiation, the thallus grew as rapidly as thalli that had received no radiation. The functional significance of the seta-bearing cell is still not understood, but it has been found that these cells have the capacity to dedifferentiate and divide to form normal vegetative and seta-bearing cells. Mechanisms controlling the number of seta-bearing cells and growth of the thallus are discussed.
\end{abstract}

\section{INTRODUCTION}

With the exception of several well studied examples, such as Oedogonium (Rawitscher-Kunkle and Machlis, 1962), Volvox (Starr, 1969, 1970), Ulva (Fjeld, 1971, 1972; Føyn, 1961), and Acetabularia (Brachet and Bonotto, 1970), few species of green algae (Chlorophyta) have been used for experimental studies of developmental morphology. No studies on the control of cell division, cell differentiation or dedifferentiation are known in the chlorophycean order Ulotrichales.

The alga Coleochaete scutata (Ulotrichales) has several features of growth and development which facilitate the application of modern experimental techniques. C. scutata is an epiphyte commonly found growing on the submerged stems of Typha (cattail), Carex (sedge), or on glass debris. In culture, this feature is useful since the alga will grow very well, adhering to glass slides or coverslips. Ths thallus consists of a platelike growth of cells one cell layer thick except in older thalli, where the

'Supported by NSF Grant GB 36646 and NIH HL 15740 to $\mathrm{MB}$ and a University of Michigan Faculty Research Grant from the Rackham Graduate School to GM. central portion may become two cclls thick. Prior to the onset of sexual reproduction, the thallus consists only of undifferentiated vegetative cells and differentiated seta-bearing cells (SBC) which are distinguished by the production of a tubeshaped extension of the cell wall (the seta collar) through which a continuous hyaline cytoplasmic thread is extruded (McBride, 1968). In addition, the chloroplast of the SBC assumes a crescent shape and revolves in the cell lumen around the base of the seta collar (Geitler, 1961). Neither the function of the SBC nor the mechanism of chloroplast movement is understood. SBC differentiate directly from vegetative cells and normally represent $3-5 \%$ of the total number of cells in a thallus. A paper on their ultrastructure is being prepared for presentation elsewhere.

Thallus development begins when a biflagellate zoospore settles on the substrate, loses its flagella, and undergoes a division that is usually parallel to the long axis of the cell (see A and R, Fig. 1). At this point, one of these two cells cleaves a small cell from its free face which differentiates within 24-48 hr into the first or primary seta-bearing cell of the thallus ( $D$ and $E$, 

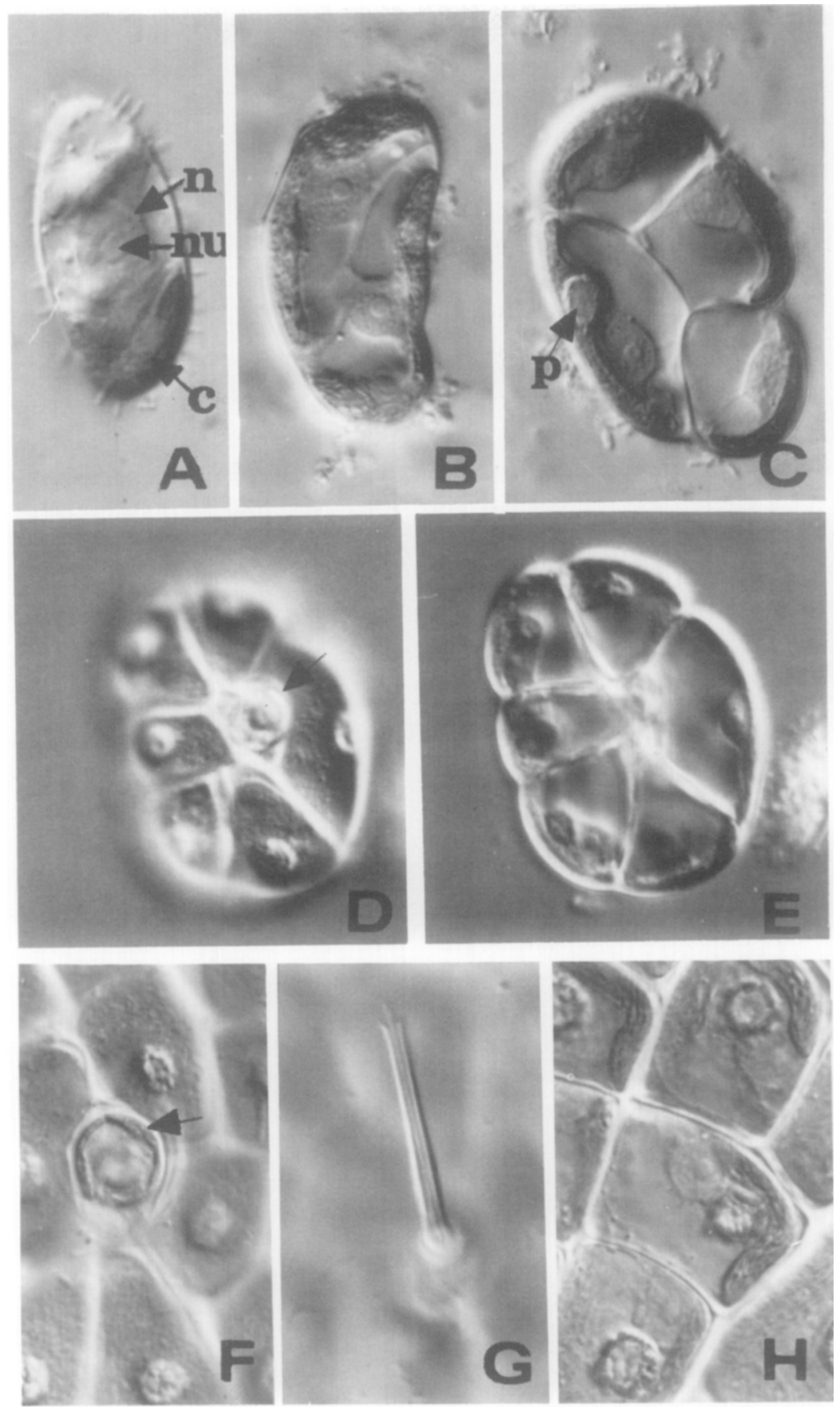

Fig. 1. (A) Zoospore of Coleochaete scutata after losing flagella and settling. The nucleus (n). nucleolus (nu), and chloroplast (c) can be readily seen ( $\times 1180$ ). (B) After first division of developing thallus ( . 1180). (C) Four-cell stage of young thallus. Pyrenoids ( $p$ ) can be distinguished in the chloroplasts. By this stage of development, the primary seta-bearing cell has been cleaved and is situated in the center of the thallus, but it is out of the plane of focus $(\times 1180)$. (D) Surface view of young thallus showing primary seta-bearing cell (arrow) $(\times 412)$. (E) Optical cross section of thallus seen in $\times 1 \mathrm{D}(\times 412)$. (F) Crescent-shaped chloroplast (arrow) (3f primary seta-bearing cell on older thallus $(\times 1150)$. (G) Seta collar-the tubular extension of a seta-bearing cell-showing the stream of cytoplasm passing through it $(-1150)$. (H) Normal vegetative cells of $\mathrm{C}$. seutata $(\times 1150)$. 
Fig. 1). Thereafter, the two basal cells divide again, each in a plane perpendicular to the original plane of division forming a 4-celled platlike thallus (C, Fig. 1). Subsequent cell divisions are essentially restricted to marginal cells and are both parallel and perpendicular to the margin of the thallus. With the exception of older thalli in which occasional internal cells may divide once in a plane parallel to the substrate. As thallus growth proceeds, certain vegetative cells differentiate into setabearing cells. A thallus may grow as large as $5 \mathrm{~mm}$ in diameter under proper culture conditions.

This investigation was designed to determine the effect of SBC destruction on the growth of the thallus, the factors controlling the number of SBC per thallus, and the capacity for dedifferentiation, or totipotency, of SBC. Laser microbeam irradiation was used to selectively destroy cells of the thallus.

\section{MATERIALS AND METHODS}

Stock cultures of Coleochaete scutata originally isolated from a fish tank were grown on glass slides in soil water or "Chu 10" medium (Chu, 1942). To obtain experimental material, mature thalli were scraped free from the glass slides and placed in fresh Chu 10 media in plastic petri dishes containing clean $43 \times 50 \mathrm{~mm}$ coverslips. Zoospores were released from these thalli within 2-4 days, settled on the coverslips, and began to divide within 3-6 days. The cultures were maintained at $66-70^{\circ} \mathrm{F}$ under 300 foot-candle "Grolux" fluorescent light with a 16 -hr day-8 hr night light regime. Prior to irradiation, coverslips which contained young thalli of approximately $110-125 \mu \mathrm{m}$ in diameter with 2-4 seta-bearing cells were transferred to Rose culture chambers filled with $\mathrm{Chu}$ 10 medium for the duration of the experiment.

The laser microbeam system has been described elsewhere (Berns, 1971). The blue-green beam ( $488 \mathrm{~nm}$ and $514 \mathrm{~nm}$ ) of a pulsed argon laser is deflected into a Zeiss photomicroscope and focused to a beam diameter of one or a few microns by a standard 40X Neofluar phase objective. The Rose chamber containing the growing thalli is placed under the microscope, and the target thallus is viewed through a television system that is attached to the microscope. The cell to be irradiated is moved under a cross-hair (which denotes the focal point of the laser) on the television monitor by manipulation of the microscope mechanical stage. The cross-hair is located directly over the single large chloroplast and the laser discharged. There is enough absorption of the laser wavelengths by the chloroplast pigments to result in destruction of the irradiated cell. An ultrastructural analysis of laser microirradiated cells will be published elsewhere. Energy density in the focused spot was controlled by attenuating the laser beam with calibrated neutral density filters. Laser output was continually monitored with a vacuum photodiode. Total energy density in the focal spot was 5-15 microjoules. Each irradiated cell received 1-2 pulses of laser energy. In the first experimental series in each of two thalli with more than 50 cells, all seta-bearing cells were destroyed by the laser. In each of two other thalli with more than 50 cells, an equivalent number of randomly selected vegetative cells were destroyed. Two control thalli were not exposed to radiation. In the second experimental series, thalli selected for irradiation consisted of 2-4 vegetative cells and a single seta bearing cell. All vegetative cells of each thallus were destroyed leaving the center seta cell unaffected.

Drawings of pre- and post-irradiated thalli were made with camera lucida, and the photographs were taken with $35 \mathrm{~mm}$ Zeiss Ikon Voigtländer camera attached to a Zeiss microscope equipped with a Nomarski optical system. 

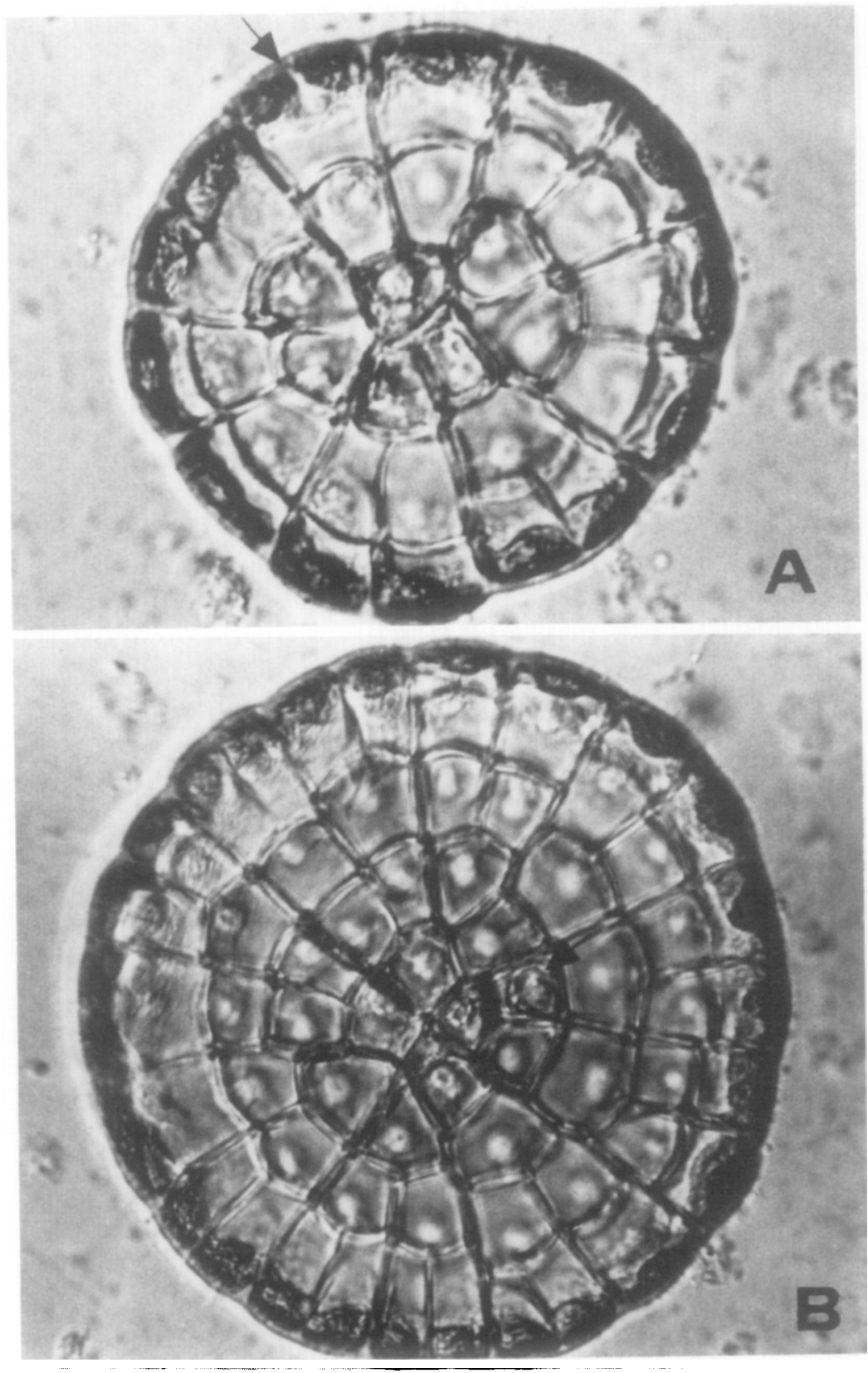

Fig. 2. (A) Young thallus of Coleochaete scutata. Normal growth occurs when the marginal cells of the thallus undergo division in planes parallel or perpendicular to the margin of the thallus. One cell in the thallus (arrow) is beginning to undergo division $(\times 535)$. (B) Older thallus of $C$. scutata, one of the vegetative cells near the center of the thallus has differentiated into a seta-bearing cell (arrow) ( $\times 4.35)$.

\section{RESULTS}

\section{The Effect of SBC Destruction}

Normal thallus development, measured in terms of division of the marginal cells, was not impaired when the seta-bearing cells of a thallus were destroyed by laser microirradiation (Table 1). The instantancous growth rate of thalli that had all of their seta cells destroyed was $0.0103 \mathrm{hr}^{-1}$. 
This figure is not significantly different from the growth rate in the control thalli (0.0108 $\mathrm{hr}^{-1}$; see Table 1). Similarly, destruction of three random vegetative cells did not adversely affect the growth of the thalli (see Table 1). Most striking, however, was the fact that within $24 \mathrm{hr}$ after the seta-bearing cells were destroyed, other vegetative cells of the thallus began to differentiate into new seta-bearing cells (see Table 2 and Fig. 3). After 120 hours, the number of SBC in irradiated thalli was not significantly different from the control thalli $\left[\chi_{(1)}^{2}=0.0219(0.5<p<\right.$ $0.7)$ and $0.602(0.3<p<0.5)$ for thalli 1 and 2, respectively]. Furthermore, irradiation of the vegetative cells did not affect the number of SBC in the thalli $\left[x_{(1)}\right.$ $=0.0218(0.8<p<0.9)$ and $1.581(0.2<$ $p<0.3$ ), for thalli 1 and 2, respectively].

When seta-bearing cells were destroyed by microbcam irradiation, they rapidly lost integrity and turgor pressure. Within a few days, the contents of the cell were gone, and one or more of the surrounding vegetative cells had begun to expand into the space vacated by the seta-bearing cell. If this space was large enough, the cell or cells invading it often underwent a division (note cell No. 16, Fig. 3) -a feature which is usually restricted to the marginal cells of the thallus (Fig. 3). A similar phenomenon was observed in thalli where vegetative cells, equivalent in number to the setabearing cells destroyed in the previous thalli, were destroyed by laser microir-

TABLE 1

Number of Cells in Thallus; and Growth Rates of Thalli

\begin{tabular}{|c|c|c|c|c|c|c|c|c|c|}
\hline \multirow[t]{4}{*}{ Time } & \multicolumn{9}{|c|}{ Treatments } \\
\hline & \multicolumn{3}{|c|}{ A } & \multicolumn{3}{|c|}{$\mathrm{B}$} & \multicolumn{3}{|c|}{$\mathrm{C}$} \\
\hline & \multicolumn{2}{|c|}{ Control } & \multirow[t]{2}{*}{ Average } & \multicolumn{2}{|c|}{$\begin{array}{c}\text { Thalli with } 3 \\
\text { seta-bearing } \\
\text { cells irradiated }\end{array}$} & \multirow[t]{2}{*}{ Average } & \multicolumn{2}{|c|}{$\begin{array}{c}\text { Thalli with } 3 \\
\text { veget ative } \\
\text { cells irradiated }\end{array}$} & \multirow[t]{2}{*}{ Average } \\
\hline & 1 & 2 & & 1 & 2 & & 1 & 2 & \\
\hline Pre-irradiation & 55 & 39 & 47 & 60 & 42 & 51 & 43 & 48 & 46 \\
\hline Post irradiation $24 \mathrm{hr}$ & 77 & 60 & 69 & 87 & 59 & 73 & 63 & 68 & 66 \\
\hline Post irradiation $48 \mathrm{hr}$ & 95 & 71 & 83 & 112 & 69 & 92 & 68 & 77 & 73 \\
\hline Post irradiation $120 \mathrm{hr}$ & 203 & 157 & 180 & 215 & 149 & 182 & 153 & 176 & 165 \\
\hline Total new cells & 148 & 117 & 133 & 155 & 107 & 131 & 110 & 128 & 119 \\
\hline Growth rate $\left(h \mathbf{r}^{-1}\right)$ & \multicolumn{3}{|c|}{$0.0108 \pm 0.0014^{a}$} & \multicolumn{3}{|c|}{$0.0103 \pm 0.0014^{a}$} & \multicolumn{3}{|c|}{$0.0103 \pm 0.0018^{a}$} \\
\hline
\end{tabular}

${ }^{a} 95 \%$ confidence intervals.

TABLE 2

Number of Seta-Bearing Cells in Thallus ${ }^{a}$

\begin{tabular}{lcccccc}
\hline & Control thalli & & $\begin{array}{c}\text { Thalli with } 3 \\
\text { seta-bearing } \\
\text { cells irradiated }\end{array}$ & & & $\begin{array}{c}\text { Thalli with } 3 \\
\text { vegetative } \\
\text { cells irradiated }\end{array}$ \\
\cline { 2 - 6 } & 1 & 2 & 1 & 2 & 1 & 2 \\
\hline Initial, pre irradiation & 2 & 3 & 4 & 4 & 2 & 2 \\
Initial, post irradiation & 2 & 3 & 1 & 1 & 2 & 2 \\
Final number of seta cells & 7 & 8 & 8 & 8 & 6 & 4 \\
Final \% seta cells & $4.5 \%$ & $3.9 \%$ & $5.4 \%$ & $3.7 \%$ & $3.4 \%$ & $2.6 \%$ \\
\hline
\end{tabular}

${ }^{a}$ See text for statistics. 

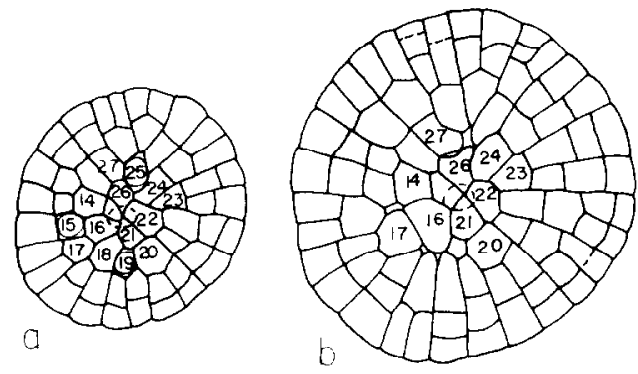

central SBC remains (Figs. 5A, 6A). In each of eight experiments, the central SBC demonstrated its capacity to dedifferentiate, divide, and produce a new thallus. The SBC retained its seta collar but appeared to cease secreting the seta material, the chloroplast lost its characteristic crescent shape and ceased to revolve, and within 72 hr the SBC had clearly begun to enlarge (Figs. 5B, 6B). Cell enlargement continued for $72-140 \mathrm{hr}$ until division occurred. The cells derived from the SBC were normal and began to grow and divide as marginal
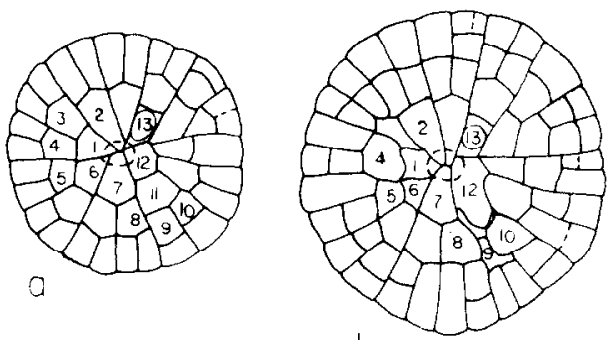

L

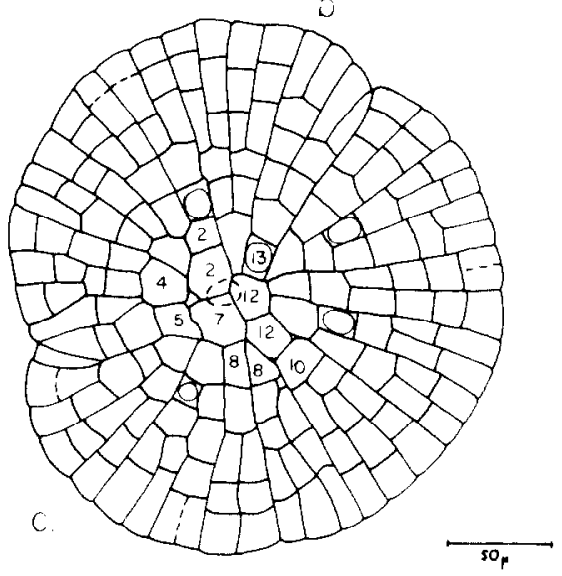

FIG. 4. (A) Prelaser drawing of a thallus in which three nonseta-bearing cells $(1,6,11)$ were irradiated with the laser microbeam. Cells 3 and 9 were also destroyed by irradiation of cells 1 and 11 . respectively. Setae are present in the thallus in the center cell and cell No. 13 inote that presence of seta-bearing cell is denoted by large circle drawn in interior of cell). (B) Same thallus 24 hours after irradiation. Adjacent cells have partially expanded to fill spaces left by the five dead cells. (C) Drawing of thallus $120 \mathrm{hr}$ after irradiation. Cell division has occurred in cells 2. 8. and 12. Note also the formation of + new seta-bearing cells (circles). 

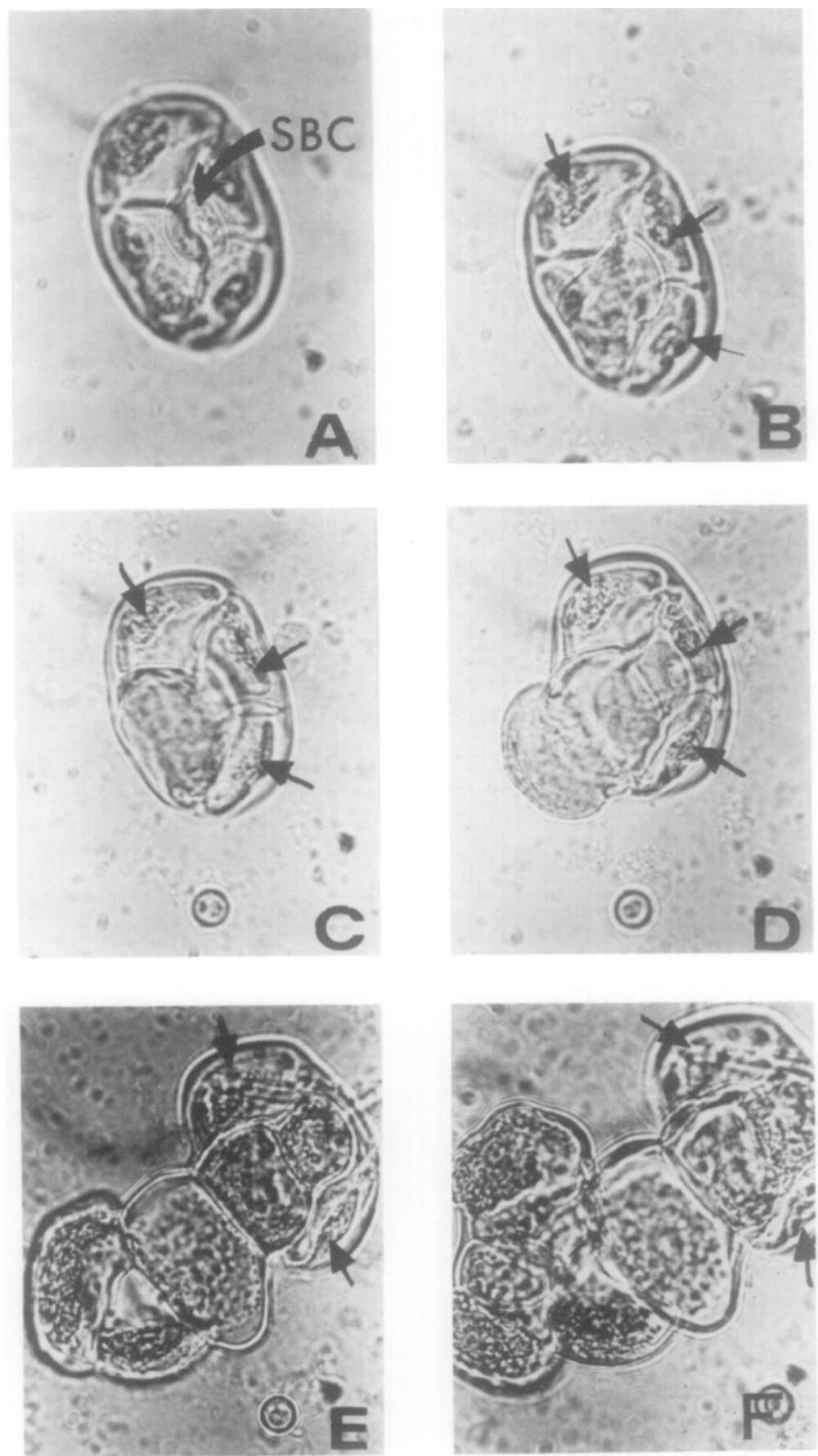

Fig. 5. (A) Five-celled thallus of Coleochaete scutata immediately after the four marginal cells have been irradiated by laser microbeam, leaving only the central SBC (arrow) alive $(\times 412)$. (B) Same thallus $72 \mathrm{hr}$ after irradiation. Note that the marginal cells have not divided and their contents appear to be disintegrating (arrows). The SBC, however, has enlarged considerably $(\times 412)$. (C) At 96 hours post-irradiation, the SBC has enlarged until it has overgrown one of the marginal cells $(\times 412)$. (D) At 120 hours post-irradiation, the SBC has divided $(\times 412)$. (E) At 144 hours post-irradiation, the derivatives of the SBC are beginning to grow and divide as typical marginal thallus cells $(\times 412)$. (F) At 192 hours post-irradiation, continued normal growth of cells derived from SBC, remains of irradiated marginal cells marked by arrows $(\times 412)$. 

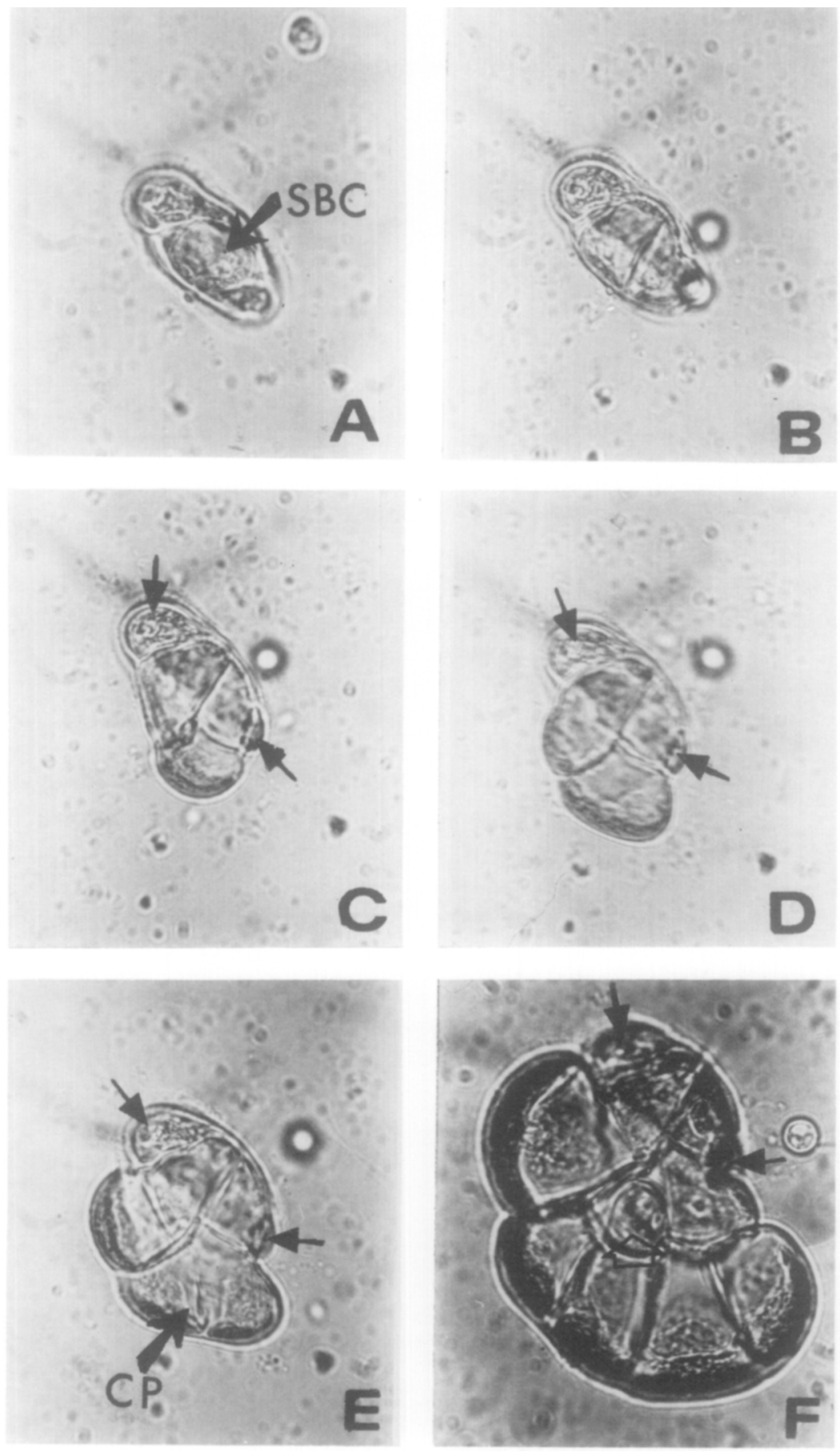

FIG. 6. (A) Three-celled thallus $48 \mathrm{hr}$ post-irradiation, the central SBC (arrow) has already begun to expand $(\times 412)$. (B) At $72 \mathrm{hr}$ post-irradiation, the enlarged SBC has divided $(\times 412)$. (C) At 96 hr post-irradiation, the cell derived from the $\mathrm{SBC}$ has divided and the new thallus is beginning to overgrow the dead cells (arrows) $(\times 412)$. (D) At $120 \mathrm{hr}$ post-irradiation, the new thallus is composed of 4 cells $(\times 412)$. (E) At $144 \mathrm{hr}$ post-irradiation, the largest cell is undergoing cytokinesis. Note cell plate (CP) tormation $(* 41 \%)$. (F) At $192 \mathrm{hr}$ post-irradiation, the marginal cells of the thallus apppear to be growing in a normal fashion fcompare with Fig. 2A). However, they have not yet formed a round thallus typical of uninterrupted development: remains of irradiated cells are marked by arrows; one of the internal cells of the new thallus has differentiated into a SBC (open arrow) $(\times 412)$. 
cells of an undisturbed thallus do. The experiments were not followed long enough to determine if these thalli would eventually develop into typical round forms found in nature. However, marginal growth appeared normal in all cases. The single SBC that gave rise to the new thallus never redifferentiated into another SBC. However, other cells of the new thallus did become SBC (open arrow, 6F).

\section{DISCUSSION}

Several conclusions may be drawn from these data. In thalli with more than 50 cells, destruction of the SBC (or an equivalent number of vegetative cells) does not radically alter the survival or normal growth of the thallus. Thus, although the exact function of the SBC is not known, it does not appear they are necessary for immediate survival (within $24 \mathrm{hr}$ ). However, since differentiation of new SBC is induced, it is clear that some mechanism for controlling the number and differentiation of seta-bearing cells exits in this organism. The exact nature of this mechanism is not clear but since seta-bearing cells continuously extrude cytoplasmic material into the environment directly surrounding the thallus (McBride, 1967, 1968). It is tempting to hypothesize a feedback control system governed by the seta-bearing cells themselves. Additional evidence for the regulation of $\mathrm{SBC}$ number comes from their distribution. The cells are not randomly scattered among the thallus but seem to be separated at regular intervals, rather like squares on a checker board (Korn, 1969). In constructing a model of the development of Coleochaete, Korn (1969) assumed that each SBC produced an inhibitory factor that diffused into neighboring cells and prevented these cells from forming seta. This assumption is not violated by our results. Experiments are being designed to test this hypothesis.

Since cell enlargement and subsequent division normally are restricted to the mar- ginal cells of the thallus, it is significant that internal cells, adjacent to either setabearing cells or vegetative cells that were destroyed, enlarged to occupy the vacated space. It is also significant to note that if the cell expansion was great enough, these cells occasionally divided. It is thus obvious that internal cells of $C$. scutata thalli have not lost their capacity for growth and division. It seems clear that cell enlargement and subsequent division are restricted bascially by external pressure. Related quantitative feulgen microspectrophotometric studies have shown that the internal cells of the C. scutata thallus remain at the Gl (equivalent to the DNA level of a telophase nucleus) level of DNA synthesis. Apparently, the release of lateral pressure by destroying adjacent cells triggers DNA synthesis, which eventually culminates in cell enlargement and division (Hopkins and McBride manuscript in preparation). This capability has a distinct adaptive advantage: since epiphytic algae are constantly subject to grazing by aquatic snails and other invertebrates, even a small portion of thallus left intact from grazing could begin regular vegetative growth anew. The peripheral pressure hypothesis does not explain why the cells of the free face of that thallus do not continue to expand and divide producing growth perpendicular to the substrate. Indeed, some older central cells may divide once, forming portions of the thallus two cell layers thick, but progress in this direction ceases. This problem must remain unresolved for the present. Other observations do substantiate the pressure hypothesis however. When two adjacent thalli on a cover slip grow together, the peripheral cells cease dividing as soon as they contact each other. This may indicate that the number of sides of the cell open for expansion is an important controlling mechanism in cell expansion and division in $C$. scutata.

The totipotency of the central SBC (and 
presumably other $\mathrm{SBC}$ of older thalli) is clearly demonstratable when the vegetative cells of a young thallus are destroyed by laser microbeam irradiation. In all eight cases the central SBC appeared to exhibit a classic dedifferentiation: (1) loss of differentiated state, (2) proliferation, and (3) redifferentiation in two directions (into vegetative cells and $\mathrm{SBC}$ ). It is obvious that the remarkably convenient cellular growth and arrangement of the C. scutata thallus can be profitably studied by precise laser microsurgery, radioisotope, quantitative DNA microspectrophutometry, and electron microscope techniques. This paper and related experiments under way have initiated an experimental approach to classical developmental problems of control of cell growth, division, differentiation, and totipotency in the ulotrichalean green algae.

\section{REFERENCES}

Berns, M. (1971). A simple and versatile argon laser microbeam. Exp. Cell. Res. 65, 470-473.

Brachet, J., and Bonotro, S., eds. (1970). "Biology of Acetabularia" Proc. First. Int. Svmp. on Acetabularia, Brussels. Acadmic Press, New York.

Chu, S. P. (1942). The influence of the mineral composition of the medium on the growth of plank. tonic algae. Part 1. Methods and culture media. $J$. Ecol. 30, 284-325.

FJEID, A. (1971). Genetic control of cellular differenti- ation in Ulva mutabilis. Induced chimeras. Hereditas 69, 59-66.

FJELD, A. (1972). Genet ic control of cellular different $\mathrm{i}$ ation in Llva mutabilis. Gene effects in early development. Develop. Biol. 28, 326-34.3.

F $\phi$ yn, B. (1961). Globose, a recessive mutant in (lva mutabilis. Bot. Mar. 3, 60-64.

Gerrler, L. (1961). Spontaneous partial rotation and oscillation of the protoplasm in Coleochaete and other chlorophyceae. Amer. J. Bot. 48, 738-741.

Hopkins, A., and McBride, G. (1973). A Microspectrophotometric study of the nuclear cycle in Coleochaete scutata. Manuscript in preparation.

Kors, R. W. (1969). A Stochastic approach to the development of Coleochaete. J. Theor. Biol. 24, $147-168$.

L $\phi$ vise, A. (1968). On the use of multicellular alga (Ulva mutabilis Foyn) in the study of general aspects of growth and differentiation. Nvtt. Mag. Zool. 33, 39-49.

McBride, G. (1967). Features of the ultrastructure of Coleochaete. J. Phycol. 3, Suppl., i (Abstract).

McBride, G. (1968). Ultrastructure and cytokinesis in selected green algae. Ph.D. Thesis. Univ. of California at Berkeley.

McBride, G. (1971). The flagella base in Coleochaete and its evolutionary significance. J. Phvcol. 7 , Suppl., 13 (Abstract).

Rawitscher-KLnkel, E., and Machlis, L. (1962). The hormonal integration of sexual reproduction in Oedogonium. Amer. J. Bot. 49, 177-183.

STarr, R. (1969). Structure, reproduction and differ entiation in Volvox carteri $\mathbf{F}$. nagariensts. Iyengar. Strains HK9 and HL10. Arch. Protistenk. 111, $214-222$.

STARR, R. (1970). Control of differentiation in Volvox. Develop. Biol.. Suppl. 4, 59-100. 